\title{
Facial paralysis associated to hypothyroidism in a dog
}

\section{Paralisia facial associada a hipotireoidismo em um cão}

\author{
Felipe Gazza Romão ${ }^{1 *}$; Mariana Isa Poci Palumbo \\ Josyanne Christine Oshika²; Luiz Henrique de Araújo Machado ${ }^{3}$
}

\begin{abstract}
The hypothyroidism is the most commonly endocrinopathy in dogs, that occurs preferentially in middle-aged pure breed. The clinical signs associated with hypothyroidism are variable, many times non-specific, including metabolical, dermatological or cardiovascular. The main laboratorial findings are non-regenerative anemia and hypercholesterolemia. Hyponatremia, increase on alanine transferase and alkaline phosphatase activity also can be observed in a lower frequency. There are some reports of peripheral neuropathies caused by hypothyroidism, but the pathophysiology of this process is still unknown. There are specific diagnostic tests that can be used to help diagnose hypothyroidism, and those should be aligned together with the animal's clinical symptoms. The thyroxine stimulating hormone, and free and total thyroxine concentrations are the most used tests. A Pit Bull dog, female, over weighted, was treated presenting left facial paralysis. Thyroid function tests confirmed hypothyroidism. The animal was treated with hormonal replacement and there was improvement in clinical signs in 40 days, confirming that hypothyroidism was facial paralysis' cause.
\end{abstract}

Key words: Hypothyroidism, obesity, facial paralysis, thyroxine

\section{Resumo}

O hipotireoidismo é a endocrinopatia mais comum em cães, que acomete preferencialmente animais de meia-idade de raça pura. Os sintomas clínicos são bastante variados, e muitas vezes inespecíficos, incluindo alterações metabólicas, dermatológicas ou cardiovasculares. Os principais achados laboratoriais são anemia arregenerativa e hipercolesterolemia. Hiponatremia, aumento da atividade da fosfatase alcalina e da alanina aminotransferase também podem ser observadas com menor frequência. Existem alguns relatos de neuropatias periféricas causadas por hipotireoidismo, mas a fisiopatologia deste processo é ainda desconhecida. Existem testes específicos, utilizados no auxílio ao diagnóstico do hipotireoidismo, que devem ser interpretados em conjunto com os sinais clínicos do animal. As concentrações de tireotopina (TSH), tiroxina (T4) livre e total são os testes hormonais mais utilizados. Uma cadela da raça Pit Bull, obesa, foi atendida apresentando paralisia facial esquerda. Os exames de função tireoideana confirmaram hipotireoidismo. $\mathrm{O}$ animal foi tratado com reposição hormonal e houve melhora dos sinais clínicos em um período de 40 dias, confirmando o hipotireoidismo como causa da paralisia facial.

Palavras-chave: Hipotireoidismo, obesidade, paralisia facial, tiroxina

${ }^{1}$ Mestrandos do Dept $^{\mathrm{o}}$ de Clínica Veterinária, Universidade Estadual Paulista. UNESP, Botucatu, SP. E-mail: fgazza_vet@ hotmail.com; palumboma11@yahoo.com.br

2 Residente do Dept ${ }^{\mathrm{o}}$ de Clínica Veterinária, UNESP, Botucatu, SP. E-mail: josyanne_oshika@hotmail.com

3 Prof. Dr. Assistente do Dept ${ }^{\circ}$ de Clínica Veterinária,UNESP, Botucatu, SP. E-mail: henrique@fmvz.unesp.br

Autor para correspondência 


\section{Introduction}

Thyroid gland is responsible for active thyroid hormones production, thyroxine $\left(\mathrm{T}_{4}\right)$ and triiodothyronine $\left(\mathrm{T}_{3}\right)$, under the influence of thyrotropin (TSH) control from the pituitary gland and release of thyrotropin-releasing hormone (TRH) from the hypothalamus. Hypothyroidism may, therefore, arise from a defect in any of these areas (DIXON, 2009).

Hypothyroidism is a common endocrinopathy in dogs, caused by a deficiency in the hormone synthesis by thyroid (SURANITI et al., 2008); it is more often observed in medium to large sized pure breeds, occurring preferentially between 3 to 8 years old. Some breeds, as Doberman, Golden Retriever, Irish Setter, Airedale Terrier and Beagle seem to be predisposed (DAMINET, 2008). The animal in the present report does not fit the epidemiological features described, since it is a 9 years old Pit Bull dog.

The classic signs of hypothyroidism in dogs include: obesity, lethargy, alopecia, "rat tail" and reproductive abnormalities. Central or peripheral neuropathies, cardiovascular alterations, gastrointestinal disorders, among others, are less common (PANCIERA; CARR, 2007).

Neurological signs are rare in primary hypothyroidism and may be caused by myxedematous or atherosclerotic changes secondary to hyperlipidemia. The signs can include seizures, circling, disorientation and coma (SURANITI et al., 2008). Other neurological manifestations include polyneuropathy and focal neuropathy. The pathogenesis of peripheral nerve disease associated with the hypothyroid state is not completely understood (FORS, 2006), although it is believed that it is a reflect of a deficit in energy metabolism and resultant disturbance in axonal transport and
Schwann cells dysfunction (DAMINET et al., 2003; FORS, 2006). Another possible explanation for the cranial nerves' paralysis (such as facial and vestibulocochlear) would be the resulting compression of myxedematous deposit in nerves or in the head and neck tissues (FORS, 2006).

\section{Case Report}

A 9-years-old female Pit Bull dog was brought to the School of Veterinary Medicine and Animal Science of Sao Paulo State University - FMVZ Botucatu - presenting apathy, left side facial paralysis and palpebral ptosis for two days. The owner also reported that the dog had been presenting weakness and exercise intolerance lately.

During physical examination the animal presented normal parameters (hydration, mucosas, capillary refill time, heart beat and respiratory frequencies and rectal temperature); apathy, obesity and generalized pilous rarefaction were observed during inspection (Figure 1-B).

Neurological examination revealed left side facial paralysis, with palpebral ptosis and facial asymmetry (Figure 1-A). The facial sensitivity was bilaterally preserved. The animal didn't present reaction to threat on left ocular globe, but its vision was preserved. Other cranial nerves, postural reactions and spinal reflexes were normal during evaluation. Motor or proprioceptive deficits were not verified and consciousness level was preserved.

The laboratorial exams showed mild normocytic normochromic anemia (hematocrit 35\%; reference range 37 to $52 \%$ ) and hypercholesterolemia (437 $\mathrm{mg} / \mathrm{dL}$; reference range 125 to $300 \mathrm{mg} / \mathrm{dL}$ ). The leucogram and platelet count, renal function, alkaline phosphatasis and triglycerides were within reference values. 
Figure 1: A) Dog presenting facial asymmetry; B) Obese dog, presenting generalized pilous rarefaction.

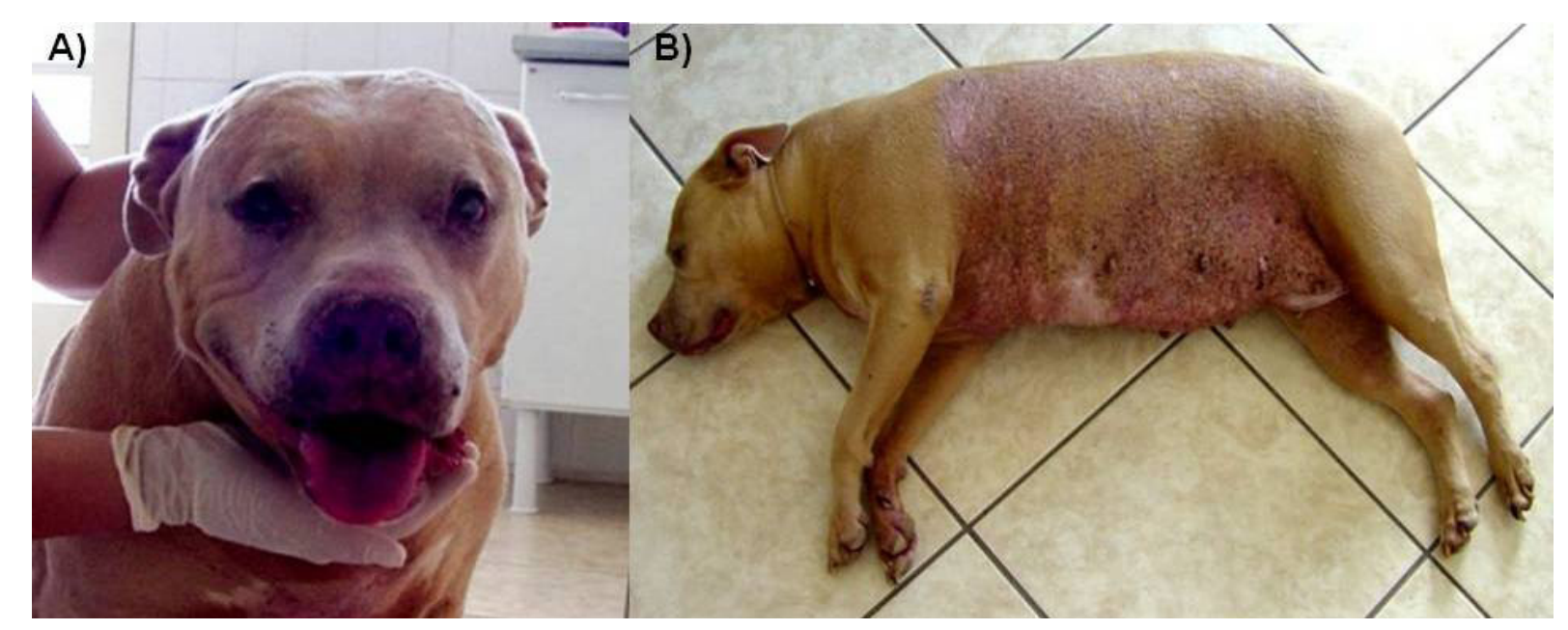

Hypothyroidism was suspected after physical and laboratorial findings, added to the owner's complaint. The diagnosis was subsequently confirmed by thyrotropin (TSH) and free thyroxine $\left(\mathrm{T}_{4}\right)$ concentrations (Table 1).

It is important to observe that the thyroid function tests were performed using the method of equilibrium dialysis, which is considered the most reliable method in the diagnosis of hypothyroidism. After the statement of diagnosis, the animal was treated with manipulated sodium levothyroxine $(0,002 \mathrm{mg} / \mathrm{kg}$, every 12 hours $)$ and achieved neurological improvement after approximately 40 days (return of threat reflex, facial movement and symmetry). In addition, the patient became more active and lost $5 \mathrm{~kg}$ in one month of treatment.

The owner reported that the animal was lethargic and over weighted for several years, features that are usually present in hypothyroidism, in part by decreased metabolic rate $(15 \%$ compared to normal dogs) (PANCIERA, 2001), and also by mucopolysaccharides accumulation in the subcutaneous tissue (myxedema), named as the responsible for weight gain in affected animals (LOMENICK; EL-SAYYID; SMITH, 2008).

The results of hemogram, biochemistry panel and urinalysis can confirm the hypothyroidism diagnosis and rule out other disorders. A moderate normocytic normochromic nonregenerative anemia occurs in 30 to $40 \%$ of the cases (PANCIERA, 2001). Hypercholesterolemia occurs in $75 \%$ of hypothyroid dogs, thanks to increased high density lipoprotein concentrations. Hypertriglyceridemia and hyperglycemia may also occur in $88 \%$ and $49 \%$ of dogs, respectively (SCOTT-MONCRIEFF, 2007). The dog in this report presented the hematological and biochemical results consistent with those reported in the literature, like normochromic normocytic anemia, hypercholesterolemia and hypertriglyceridemia.

Table 1. Results and Reference values for TSH and Free T4 serum concentration.

\begin{tabular}{lll}
\hline Test & Results & Reference values \\
\hline TSH & $1.16 \mathrm{ng} / \mathrm{mL}$ & 0.1 to $0.5 \mathrm{ng} / \mathrm{mL}$ \\
Free $\mathrm{T}_{4}$ & $0.15 \mathrm{ng} / \mathrm{mL}$ & 0.7 to $2.6 \mathrm{ng} / \mathrm{mL}$ \\
\hline
\end{tabular}


The diagnosis is based on laboratory evaluation of thyroid function and response to treatment (SCHUNK, 1990; SCOTT-MONCRIEFF et al., 1998; DAMINET et al., 2003), as observed in this report. Unfortunately, the diagnosis becomes more complicated because too many factors can influence tests results, leading to a decreased serum thyroxine levels, for example (MOONEY, 2007).

Thyrotropin (TSH) levels, associated to thyroxine and free thyroxine concentrations are important tools used in the diagnosis of this disease (DAMINET et al., 2003). Hypothyroidism leads to decreased basal concentrations of thyroid hormones and increased TSH levels, because of the lack of negative feedback control of TSH production, which is a function of $\mathrm{T}_{4}$ produced by the adenohypophysis (SCOTT-MONCRIEFF et al., 1998).

Basal serum total $\mathrm{T}_{4}$ has traditionally been the main element for the diagnosis of canine hypothyroidism and remains an excellent line of diagnostic test for the disease. It is a cheap and sensitive marker for hypothyroidism, but low values do not confirm the disease, since many conditions (drug use, for example) may reduce serum levels (PANCIERA; CARR, 2007; DIXON, 2009).

The serum thyrotropin (TSH) concentration usually increases in cases of primary hypothyroidism. However, 20\% of hypothyroid animals present normal TSH levels; the exact cause of this phenomenon is not known, but it is believed that there may be anterior pituitary exhaustion, there may be a random fluctuation during the day, or there are isoforms of canine TSH that cannot be measured. The presence of a concomitant disease and secondary hypothyroidism could be other cause for normal TSH levels in animals suffering from primary hypothyroidism; for these reasons, it is not recommended to use only this test to investigate this disease (MOONEY, 2007).

The free $\mathrm{T}_{4}$ concentration is considered the most reliable diagnostic test among available options. The free fraction of thyroxine is metabolically active and available to the tissues. The equilibrium dialysis is considered the best method for determining free hormone, since other methods only attempt to estimate the free concentration of thyroxine (DIXON, 2009). The animal described here presented elevated levels of thyrotropin and decreased free thyroxine, which confirmed the initial suspicion of hypothyroidism.

The synthetic levothyroxine is the standard treatment for hypothyroidism. The initial dose is $0.02 \mathrm{mg} / \mathrm{kg} / \mathrm{day}$; this should be raised or decreased based on the clinical response and evolution of laboratorial tests results (DAMINET, 2008). The therapy prescribed in this case was $0.02 \mathrm{mg} / \mathrm{kg} /$ BID, which led to improvement in metabolic and neurological signs within 40 days, without signs of thyrotoxicosis.

With appropriate therapy, all clinical signs and other abnormalities associated with hypothyroidism are reversible. In general, metabolic symptoms such as mental retardation and lethargy are among the first to improve, which can often be observed within 7 days after the beginning of treatment. Weight loss is a constant feature of a successful treatment and a $10 \%$ reduction in weight can occur within three months (DIXON, 2009). The patient in this report lost $10 \%$ of its body weight in about 40 days, which can be regarded as a great result in treatment. In humans, it was shown that weight loss is mainly due to dissipation of fluid mucopolysaccharide (myxedema) accumulated in the subcutaneous tissue (LOMENICK; EL-SAYYID; SMITH, 2008).

\section{References}

DAMINET, S. Canine hypothyroidism: clinical aspects. Progress in the diagnosis. Pitfalls in the diagnosis and treatment. In: EUROPEAN VETERINARY CONFERENCE, 2008, 41., 2008, Amsterdam. Proceedings... Amsterdam: EVC, 2008. p. 41-44.

DAMINET, S.; CROUBELS, S.; DUCHATEAU, L.; DEBUNNE, A.; VAN GEFFEN, C.; HOYBERGS, Y.; VAN BREE, H.; DE RICK, A. Influence of acetylsalicylic acid and ketoprofen on canine thyroid function tests. 
Veterinary Journal, Londres, v. 166, n. 3, p. 224-232, 2003.

DIXON, R. M. Hypothyroidism. In: MOONEY, C. T.; PETERSON, M. E. (Ed.). Manual de endocrinologia canina e felina. São Paulo: Roca, 2009. p. 95-114.

FORS, S. Neuromuscular manifestations of hypothyroidism in dogs. The European Journal of Companion Animal Practice, Paris, v. 17, n. 2, p. 173178, 2007.

LOMENICK, J. P.; EL-SAYYID, M.; SMITH, W. J. Effect of levo-thyroxine treatment on weight and body mass index in children with acquired hypothyroidism. Journal of Pediatrics, Philadelphia, v. 152, n. 1, p. 96100, 2008.

MOONEY, C. T. Diagnosing hypothyroidism: definitive or not? In: WORLD SMALL ANIMAL VETERINARY CONGRESS, 32., 2007, Sidney. Proceedings... Sidney: WSAVA, 2007.

PANCIERA, D. L. Conditions associated with canine hypothyroidism. Veterinary Clinics of North America: Small Animal Practice, Philadelphia, v. 31, n. 3, p. 935950, 2001.
PANCIERA, D. L.; CARR, A. P. Hipotireoidismo canino. In: . (Ed.). Endocrinologia para o clínico de pequenos animais. São Paulo: Roca, 2007. p. 23-34.

SCHUNK, K. L. Diseases of the vestibular system. Progress in Veterinary Neurology, Washington, v. 1, n. 3, p. 274-354, 1990.

SCOTT-MONCRIEFF, J. C. R. Clinical signs and concurrent diseases of hypothyroidism in dogs and cats. Veterinary Clinics of North America: Small Animal Practice, Philadelphia, v. 37, n. 4, p. 709-722, 2007.

SCOTT-MONCRIEFF, J. C. R.; NELSON, R. W.; BRUNER, J. M.; WILLIAMS, D. A. Comparison of serum concentrations of thyroid-stimulating hormone in healthy dogs, hypothyroid dogs, and euthyroid dogs with concurrent disease. Journal of American Veterinary Medical Association, Illinois, v. 212, n. 3, p. 387-391, 1998.

SURANITI, A. P.; GILARDONIA, L. R.; RAMA LLAL, M. G.; ECHEVARRÍA, M.; MARCONDES, M. Hypothyroidism associated polyneuropathy in dogs: report of six cases. Brazilian Journal of Veterinary Research and Animal Science, São Paulo, v. 45, n. 4, p. 284-288, 2008. 
